\title{
sciendo
}

Folia Oeconomica Stetinensia

Volume 20 (2020) Issue 1

DOI: $10.2478 /$ foli-2020-0004
WYDZIAL NAUK EKONOMICZNYCH I ZARZA¿DZANIA

\section{IDENTIFICATION OF REGIONAL SMART SPECIALISATIONS \\ ON THE BASIS OF AGGREGATE MEASURES - \\ A CASE OF THE DOLNOŚLĄSKIE VOIVODESHIP}

\author{
Beata Bal-Domańska, Ph.D., Associate Professor \\ Department of Regional Development \\ Wroctaw University of Economics \\ Nowowiejska 3, Jelenia Góra, Poland \\ e-mail: beata.bal-domanska@ue.wroc.pl \\ ORCID: 0000-0003-0395-4259
}

Elżbieta Sobczak, Ph.D., Associate Professor

Department of Regional Development

Wroctaw University of Economics

Nowowiejska 3, Jelenia Góra, Poland

e-mail: elzbieta.sobczak@ue.wroc.pl

ORCID: 0000-0003-1912-7493

Elżbieta Stańczyk, Ph.D.

Statistical Office in Wroctaw

Otawska 1, Wrocław, Poland

e-mail: e.stanczyk@stat,gov.pl

ORCID: 0000-0002-6727-7392

Received 15 October 2019, Accepted 29 March 2020

\begin{abstract}
Research background: Strengthening endogenous potentials, enhancing competitive advantage based on research and innovation remains an important component of regional development policy. Over the years this task has been carried out through e.g. the identification and support focused on smart specialisations.

Purpose: The purpose of the assessment was to identify smart specialisations in the Dolnośląskie voivodeship and evaluate their competitiveness against the background of other voivodeships.

Research methodology: The set of diagnostic indicators as well as the dynamics and location measures calculated on their basis, and also linear ordering methods using a weights system (Synthetic Measure of Smart Specialisations - SMSS) were used to identify regional smart specialisations. A statistical analysis was conducted on the basis of data at the level of PKD divisions (Polish Statistical Classification of Economic
\end{abstract}


Activities; NACE is the EU equivalent). The identification was carried out taking into account the period 2012-2017 and focused primarily on 2017.

Results: As a result, 4 RSSs were identified, of which the first two are the mining of non-ferrous metal ores and the production of motor vehicles.

Novelty: The study proposes, based on the example of the Dolnośląskie voivodeship, the possibility of using linear ordering methods in determining the region's smart specialisations (RSS), i.e. unique regional qualities and assets, which may constitute its competitive advantage, supported by appropriate research and development facilities and essential for the development of modern and innovative sectors of the economy.

Keywords: smart specialisations, Voivodeships, PKD (NACE) divisions, linear ordering methods

JEL classification: $\mathrm{O} 11, \mathrm{O} 18, \mathrm{O} 30, \mathrm{O} 38$

\section{Introduction to the research problem}

The concept of smart specialisation consists in defining the essential assets of the region, approached as the areas featuring the greatest development and innovation potential, and next taking advantage of these assets to intensify socio-economic development, enhance innovation, as well as improving both domestic and international competitive position. Identifying smart specialisations and monitoring the effects of their development has become a challenge for the European Union countries and regions.

In 2010, the European Union adopted the Europe 2020 development strategy, which set goals to support Member States in creating smart development based on knowledge and innovation (European Commission, 2010). One of the instruments facilitating smart development was preparing the concept of regional and national areas focused on smart specialisations (regional smart specializations will be referred to as RSS). The European Commission referred to the problem of smart specialisations in the "Guide to Research and Innovation Strategies for Smart Specialisation (RIS 3)" (2012). Smart specialisation means areas of the economy, sectors or industries presenting high innovation and competitive potential. Investments in their development allows for increasing the competitiveness of regions and optimizing the use of financial resources by concentrating activities in the areas characterised by high development and innovation potential. In the years 2014-2020, the European Union provided financial support for projects covering the activities carried out in the areas of smart specialisations. 
D. Foray is considered the creator of the concept of smart specialisation, as a member of the specialist group known as "Knowledge for Growth" established to provide consultancy for the European Commission on the development of the Europe 2020 strategy (Capello, 2014). The first recorded reference to the term smart specialisation took place in 2008 (Foray, David, Hall, 2011; Lopes, Ferreira, Farinha, 2019). In D. Foray's opinion regions have the ability to discover new opportunities and to concentrate resources and competences in these newly found domains (Foray, 2015). Therefore, the main goal of smart specialization is to diversify the structure of a regional economy by generating new specialties and options for growth within that region (Landabaso, Foray, 2014; Landabaso, McCann, Ortega-Argilés, 2014).

RSS identification should be based on identifying the existing unique resources as well as their possible development potential allowing the improvement of the region's competitiveness against other regions and on a supra-regional scale. Statistical methods, in particular multivariate statistical analysis (MSA) methods can turn out to be helpful in identifying regional resources and capital. These methods can be used in the process of comprehensive measurement and evaluation of: (1) the resources and capital; (2) the importance of a given industry/services for regional economies; (3) the development potential of an individual industry/services by assessing the dynamics of changes in a given period; (4) the involvement of a particular industry/services in research and development and also innovation activity. In particular, the aforementioned goals allow implementing linear ordering tools with a weights system.

For the purpose of the strategic document development, the process of identifying areas of smart specialization in a given region was generally conducted and based on an endogenous potential diagnosis (SWOT analysis) and qualitative methods, including a type of expert panels, interviews with entrepreneurs, focus studies or surveys and social consultations. The advanced quantitative methods were used to a limited extent. The purpose of the article is to assess the usefulness of applying linear ordering methods (aggregate measures) in identifying regional smart specializations (RSS) on the basis of Polish voivodeships. Moreover, the results are discussed and based on the example of the Dolnośląskie voivodeship. The year 2017 was selected as the analysis period, additionally the information about the discussed phenomena in the selected preceding periods were supplemented.

The first part of the article presents the basics of statistical identification covering smart specializations using a synthetic (aggregate) measure and the system of weights, which allows determining to what extent statistical methods, can remain a useful tool for RSS identification.

The second part presents the analysis results of Polish voivodeships using the procedure proposed in the first part. Identifying regional smart specializations defined as branches 
of industries or services based on innovations and constituting the regional smart specializations is an important factor for the future dynamic endogenic development of regions. The results of the applied procedure are discussed and based on the example of the Dolnosląskie Voivodeship. They allow answering the question which of the industry and service sectors may turn out crucial for the development of smart specializations in a given voivodeship and also allow comparing the obtained statistical diagnosis findings with the smart specializations listed in the currently functioning strategic documents and defined based on both qualitative research and experts' knowledge.

The Dolnośląskie voivodeship is one of the well-developed regions in Poland, which is endangered by stagnation. In the subject literature it was highlighted that "Poland and its strongest regions have already fallen into the middle income trap (Geodecki et. al., 2013). This means it is unable to further improve its economic position based on traditional functions and development potentials” (Peszat, Szlachta, 2017). As K. Peszat, J. Szlachta (2017) emphasized "the very dynamic social and economic expansion of Dolnośląskie in recent decades has mostly resulted from using simple reserves such as the advantages of its geographical location (excellent transport accessibility in the European context), the privilege of having Special Economic Zones, good economic situation within world copper production, the removal of numerous barriers and limitations to economy development as a result of political transformation, as well as cheap and relatively well-educated labour force resources". One of the opportunities for the region to enter a new path of development is to strengthen the industries and services ensuring a high competitive position both in the country and internationally.

\section{Regional Smart Specialization (RSS) identification procedure}

The procedure for identifying smart specialisations at the regional/voivodeship level was based on the following stages:

1. Defining the thematic scope allowing the identification of smart specialisations and collecting statistical material at the lowest possible level of availability in terms of industry (PKD divisions; NACE is the EU equivalent) in 2017 and additionally in 2012.

2. Calculating the auxiliary indicators (dynamics measures and location indicators) at the level of PKD $l$ divisions $(l=1,2, \ldots, 73)$ for all $i$ voivodeships $(i=1,2, \ldots, 16)$.

3. Normalization of indicator values to the range $[0,1]$ using the zero unitarization method based on the minimum value and range. 
4. Determining the value of sub-measures $M R_{k}$ for $k(k=1,2,3,4)$ of RSS identification areas in $i$ voivodeships: $M R_{1}$ - industry/sector development level in 2017, $M R_{2}-$ industry/sector regional specialisation in 2017, $M R_{3}$ - industry/sector development dynamics in the years 2012-2017, $M R_{4}$ - industry/sector involvement in innovation in the years 2015-2017.

5. Determining the value of SMSS (Synthetic Measure of Smart Specialisations) as the sum of sub-measures with $w_{k}$ weights system at the division level of PKD classification:

$$
\operatorname{SMSS}_{i l}=\sum_{(k=1)}^{4} w_{k} M R_{i l k}
$$

One of the most important steps in any analysis is the selection of indicators constituting the basis for formulating conclusions. The identification of smart specialisations using quantitative methods requires access to statistical data at the level of enterprises or groups of enterprises operating within a given industry. The analysis presented in the study uses data provided by GUS (Statistics Poland) resources broken down into industries and service groups classified by $\mathrm{PKD}$ divisions (NACE is the EU equivalent). $88 \mathrm{PKD}$ divisions from section A to $\mathrm{U}$ were included in the analysis.

The analysis of the available statistical data allowed using the following variables, characterizing the scale of competitive advantages at the level of PKD divisions and voivodeships. $P$ (employed in the main workplace) variable refers to working people, thus it illustrates the social scale of activities and the importance of a given sector for regional labour markets (and indirectly the living conditions of the population). The revenues of non-financial enterprises from total activity (C) may allow indicating sectors/industries presenting above average, compared to other regions, financial results and efficiency in performing business activities. The level of industry/services modernity and internationality providing opportunities for a good position on an international market is shown by the $E$ variable, i.e. net revenues from sales of export products, goods and materials. Variable $I$ - enterprise expenditure on innovation activities carried out in the years 2015-2017, proves the innovation potential of the region, i.e. the scale of enterprise budget involved in innovation.

Due to the fact that the analysis was not focused on comparing regional economies, but on identifying the scale and significance of a given PKD division against the background of other sections in the region and the country, all variables of $M R_{1}$ measure were defined in absolute terms.

In the next stage, the first 3 variables after performing the zero unitarization method became the basis for constructing $M R_{1}, M R_{2}, M R_{3}$ sub-measures, whereas $I$ indicator gave grounds for assessing the innovation level of a given section in individual voivodeships as the $M R_{4}$ measure. 
The $M R_{1}$ sub-measure was established as the synthetic value of three key indicators: $P$, $C$ and $E$ showing the human resources of a given sector, production volume and the volume of production intended for export highlighting its international range.

The $M R_{2}$ measure shows the level of specialisation in a given voivodeship regarding a particular industry/sector against the background of the country average and was set as the location quotient (LQ) presenting the following structure:

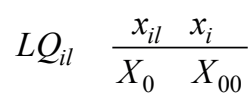

where: $x_{i l}$ - value for a given division at voivodship level; $x_{i 0}$ - total value at voivodship level, $X_{0 l}$ - value for a given division at country level, $X_{00}$ - total value at country level.

The $M R_{3}$ measure was defined as changes in the level of indicators (fixed base indexes 2012 = 100). When determining the value of dynamics indexes, allowing for the assessment of the change dynamics in a given section in 2017 against 2012, problems occurred in identifying the level of changes due to the phenomenon absence in 2012. Ultimately, in such situations, the fixed dynamics index value of 10\% was adopted arbitrarily in 2017.

Certain difficulties of a methodological nature were encountered in defining the level of innovation. They referred to the selected PKD divisions or sections, which due to the specificity of the subjective scope of cyclical surveys carried out by the Statistics Poland on innovative activity in industry and services were not included in reporting, and therefore could not be covered by the proposed process aimed at identifying regional specialisations. It referred to section A (agriculture, forestry, hunting and fishing), F (construction), division G45 (trade and repair of motor vehicles), sections I (accommodation and food service activities) and L (real estate market), division 70 (consulting activities related to managing), 74 (other professional, scientific and technical activities), 75 (veterinary) and service sections from $\mathrm{N}$ (administration services) to $U$ (extraterritorial organizations and teams). Ultimately, these sections were covered by the analysis (despite the lack of data on innovation expenditure). It allowed, firstly, the comprehensive inventory of regional potential and resources, and secondly, in the case of outstanding departments to supplement information on the level of involvement in innovation activities from other sources.

Currently the defined smart specialisations of voivodeships list activities extending beyond one department, i.e. interdisciplinary activities. The Silesia voivodeship is an example, which listed Medicine as one of the voivodeships distinguishing features in the country due to its excellence 
in numerous areas of prevention, treatment and rehabilitation and also the recognition of medical engineering products. At the same time, the following attributes of this RSS were recognized: integration of technological development and the development of public services, generating technological connections, primarily with such industries as nanotechnology, biotechnology, materials engineering and also information and communication technologies, constructing a new image of the region based on the existing and recognized clinical potential (UMWS, 2018).

The conducted analysis aimed at identifying smart specialisations at the level of the Dolnośląskie voivodeship; nevertheless in order to assess the competitive advantage of the indicated industries/sectors against the background of the other voivodeships, the calculations were carried out simultaneously for all voivodeships (it referred, in particular, to the zero unitarization procedure).

Two weight vectors were adopted in the construction of two alternative synthetic measures. The adopted weights were imposed by researchers, established in a subjective manner on the basis of substantive knowledge and the defined research objectives, i.e. the identification of smart regional specialisations. Weights systems defined and based on the distribution properties or statistical characteristics were not considered in the analysis. However, it should be mentioned that it would also be possible to introduce weights on the basis of a different basis. The subject literature distinguishes three approaches to defining weights: substantive, statistical and a hybrid one, the latter being based on the previous two. Substantive weights are set by an expert (a priori) method and refer to arguments determining the significance of a feature for a given phenomenon. Statistical weights are defined using calculation algorithms based on the information included in primary data (Walesiak, 2011). Statistical weights can be determined using, e.g. formulas which prefer the features characterised by the highest variability, more correlated with other features, or using the variable "uniqueness" indicator. More information on the methods for weighing features is presented in the following studies (Bąk, 1999; Borys, 1984; Grabiński, 1984).

The first weight vector $\mathbf{B}(0.25 ; 0.25 ; 0.25 ; 0.25)$ assumed equal weights, whereas the second specific values $\mathbf{W}(0.2 ; 0.3 ; 0.1 ; 0.4)$, so that the highest weight was assigned to expenditure on innovation activities (0.4), as an expression of commitment to knowledge and possibilities in creating new solutions increasing competitiveness. High significance was also given to specialisation $\left(M R_{2}\right)$ by assigning a 0.3 value to this measure. The level of a given sector development was presented by the $M R_{1}$ measure and assigned the weight of 0.2 . The lower level of weight resulted from the assumption that the commitment to knowledge and uniqueness of a given sector on a national and regional scale remains essential for smart 
specialisations. The dynamics of changes in the years $2012-2017\left(M R_{1}\right)$ with the weight of 0.1 was adopted as a supplement in assessing the position and development potential of a given sector in the region.

\section{Results and findings}

\subsection{Impact assessment of the adopted weights system for the synthetic measure of smart specialisations (SMSS)}

The validity assessment of the adopted weights, which differentiate the significance of individual components $\left(M R_{1}, M R_{2}, M R_{3}, M R_{4}\right)$ for smart specialisations, is an important element of the applied methodology.

In order to assess the effects of introducing weights and their impact on the description level of the investigated characteristics, i.e. innovation and specialisation, Table 1 summarizes the more important statistical parameters describing properties of the synthetic measure of smart specialisations with the system of different weights $\operatorname{SMSS}_{W}(0.2 ; 0.3 ; 0.1 ; 0.4)$ and equal ones $\operatorname{SMSS}_{B}(0.25 ; 0.25 ; 0.25 ; 0.25)$. Differences in $S M S S$ distribution parameters were observed regarding different weights. In the case of $S M S S_{W}$ with a weights system, the measure adopted lower average values and was characterized by greater skewness and variability. Assigning higher weights to specialisation and innovations increased the disparities between individual PKD divisions/sectors, strengthening the impact of those sub-measures which were assigned higher weights.

Table 1. Descriptive statistics of SMSS measures and their components

\begin{tabular}{|c|c|c|c|c|c|}
\hline Specification & Mean & $\begin{array}{c}\text { Coefficient } \\
\text { of variation }\end{array}$ & Skewness & Minimum value & Maximum value \\
\hline$S M S S_{W}$ & 0.026 & 1.2 & 5.5 & 0.003 & 0.270 \\
\hline$S M S S_{B}$ & 0.031 & 0.9 & 4.2 & 0.006 & 0.223 \\
\hline \multicolumn{7}{|c|}{ Components } & 3.3 & 0.000 & 0.245 \\
\hline$M R_{1}$ & 0.025 & 1.5 & 6.4 & 0.000 & 0.480 \\
\hline$M R_{2}$ & 0.041 & 1.3 & 5.9 & 0.019 & 0.370 \\
\hline$M R_{3}$ & 0.050 & 0.9 & 5.4 & $0.000^{*}$ & 0.236 \\
\hline$M R_{4}$ & 0.011 & 30.0 &
\end{tabular}

* Out of 88 PKD divisions, in 45 of them innovation expenditure did not occur or due to the nature of sectors are not subject to the analysis.

Source: authors' estimations. 
The distribution of SMSS measure values and their components is presented in Figure 1. It shows the outlier values of the selected division sections in the case of almost every measure. Attention can be drawn to the relatively low measure values. It is worth emphasizing that the values refer only to the situation in the Dolnośląskie voivodeship, however, in the course of their calculation the situation in other voivodeships was taken into account. Thus, the value of 0.15 in the first bar means that it is the highest PKD division value obtained in the Dolnośląskie voivodeship out of 16 voivodeships.

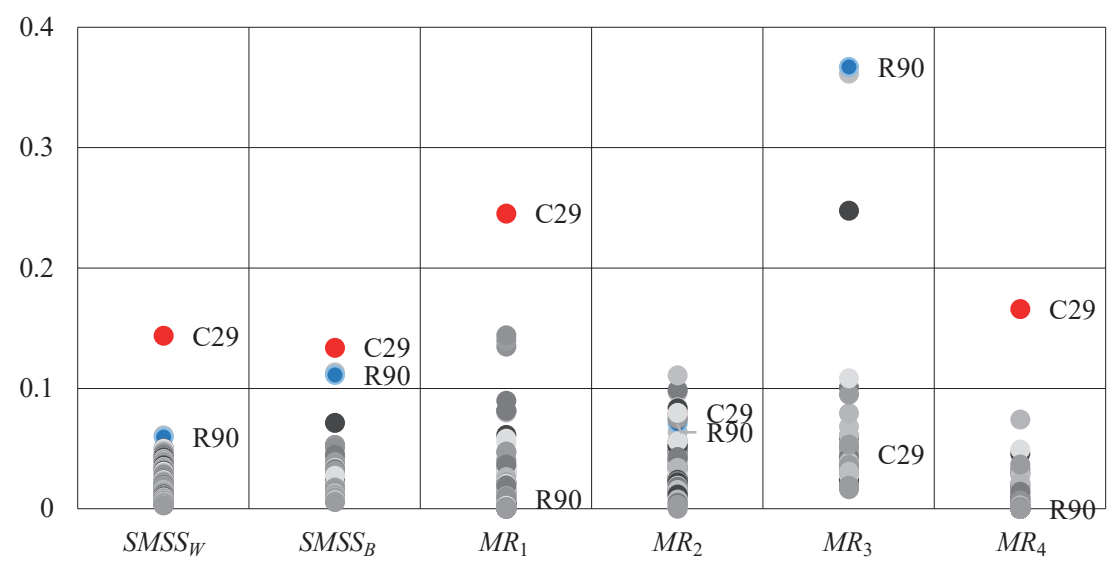

C29 - Manufacture of motor vehicles, trailers and semi-trailers, except for motorcycles; R90 - Creative, arts and entertainment activities.

Figure 1. The distribution of SMSS and their components by PKD (NACE) divisions for the Dolnośląskie voivodeship in 2017

Source: authors' compilation.

Table 2. Pearson's (Spearman's) correlation coefficients between individual SMSS measures

\begin{tabular}{|c|c|c|c|c|c|}
\hline Values & $S M S S_{W}$ & $S M S S_{B}$ & $M R_{1}$ & $M R_{2}$ & $M R_{3}$ \\
\hline$S M S S_{B}$ & $0.949^{*}$ & 1.000 & & & \\
\hline$M R_{1}$ & $0.686^{*}$ & $0.654^{*}$ & 1.000 & & \\
\hline$M R_{2}$ & $0.897^{*}$ & $0.813^{*}$ & $0.405^{*}$ & 1.000 & \\
\hline$M R_{3}$ & 0.167 & $0.457^{*}$ & -0.065 & 0.078 & 1.000 \\
\hline$M R_{4}$ & $0.902^{*}$ & $0.772^{*}$ & $0.624^{*}$ & $0.730^{*}$ & -0.067 \\
\hline Ranks & $S M S S_{W}$ & $S M S S_{B}$ & $M R_{1}$ & $M R_{2}$ & $M R_{3}$ \\
\hline$S M S S_{B}$ & $0.978^{*}$ & 1.000 & & & \\
\hline$M R_{1}$ & $0.808^{*}$ & $0.766^{*}$ & 1.000 & & \\
\hline$M R_{2}$ & $0.851^{*}$ & $0.807^{*}$ & $0.631^{*}$ & 1.000 & \\
\hline$M R_{3}$ & $0.392^{*}$ & $0.487^{*}$ & 0.088 & $0.330^{*}$ & 1.000 \\
\hline$M R_{4}$ & $0.505^{*}$ & $0.428^{*}$ & $0.495^{*}$ & $0.266^{*}$ & 0.012 \\
\hline
\end{tabular}

* Statistically significant at the level of 0.01 .

Source: authors' estimations. 
Table 2 shows the values of Pearson's/Spearman's correlation coefficients for SMSS and their components presented as the values of quantitative variables or their ranks. Their analysis results in the following conclusions:

a) the individual measure values reflecting the scale of activity $\left(M R_{1}\right)$, specialisation $\left(M R_{2}\right)$ and innovation $\left(M R_{4}\right)$ of the divisions show a moderate, statistically significant linear correlation. In particular, a clear correlation can be observed between the level of innovation and the scale and specialisation of a given PKD division. The measure illustrating the dynamics of changes $\left(M R_{4}\right)$ adds new, unique information to the analysis as it does not show any statistical significance with other sub-measures;

b) SMSS values with a different weights system present a strong linear correlation close to 1 , so slightly stronger, i.e. showing the highest consistency, if presented in the form of positions;

c) the majority of sub-measures are more compatible with the measure characterised by different $S M S S_{W}$. weights. The exception is the $M R_{3}$ dynamics measure, the consistency of which with the synthetic measure of smart specialisations SMSS after weight reduction has decreased;

d) irrespective of the adopted weights system, the highest statistical consistency with SMSS is demonstrated by the sub-measure illustrating both specialisation and innovation of the industry/sector.

Having compared the changes in the position of a given PKD division, obtained and based on SMSS at different weights levels, it should be observed that in 9 cases the position of the division did not change, in 35 cases it was improved (including 1 by more than 10 positions paper and paper products manufacturing), whereas in other cases - deterioration was recorded (including 4 by more than 10 positions).

To sum up, the introduction of a weights system allowed for increasing the statistical consistency of the obtained results with the most important elements of the smart specialisation assessment $\left(M R_{1}, M R_{2}\right.$ and $\left.M R_{4}\right)$, therefore this step should be considered appropriate.

\subsection{The identification of smart specialisations in the Dolnośląskie voivodeship with a different weights system}

The conducted procedure allowed identifying smart specialisations in the Dolnośląskie voivodeship. 15 PKD divisions were selected, which achieved the highest $S M S S_{W}$ values with a weights system. In addition, their position was presented in the $\operatorname{SMSS}_{B}$ measure with equal weights and also sub-measures (Table 3). 
Table 3. Specialisations of the Dolnośląskie voivodeship with a different weights system

\begin{tabular}{|c|c|c|c|c|c|c|c|c|c|}
\hline \multirow{2}{*}{$\begin{array}{l}\text { Symbol } \\
\text { of PKD } \\
\text { division }\end{array}$} & \multicolumn{2}{|c|}{$S M S S_{W}$} & \multicolumn{2}{|c|}{$S M S S_{B}$} & \multirow{2}{*}{$\begin{array}{l}\text { Change } \\
\text { in position }\end{array}$} & \multicolumn{4}{|c|}{ Components } \\
\hline & value & position & value & position & & $M R_{1}$ & $M R_{2}$ & $M R_{3}$ & $M R_{4}$ \\
\hline B07 & 0.267 & 1 & 0.220 & 1 & 0 & 0.139 & 0.474 & 0.031 & 0.236 \\
\hline C29 & 0.144 & 2 & 0.134 & 2 & 0 & 0.245 & 0.079 & 0.045 & 0.166 \\
\hline N80 & 0.061 & 3 & 0.114 & 3 & 0 & 0.028 & 0.064 & 0.362 & 0.000 \\
\hline R90 & 0.060 & 4 & 0.111 & 4 & 0 & 0.008 & 0.071 & 0.367 & 0.000 \\
\hline $\mathrm{C} 25$ & 0.050 & 5 & 0.051 & 8 & -3 & 0.081 & 0.040 & 0.038 & 0.046 \\
\hline $\mathrm{C} 28$ & 0.050 & 6 & 0.047 & 13 & -7 & 0.055 & 0.053 & 0.032 & 0,049 \\
\hline C17 & 0.048 & 7 & 0.042 & 18 & -11 & 0.016 & 0.037 & 0.039 & 0.074 \\
\hline G46 & 0.046 & 8 & 0.053 & 6 & 2 & 0.135 & 0.027 & 0.031 & 0.020 \\
\hline $\mathrm{C} 22$ & 0.044 & 9 & 0.049 & 10 & -1 & 0.090 & 0.050 & 0.039 & 0.019 \\
\hline $\mathrm{J} 62$ & 0.043 & 10 & 0.048 & 12 & -2 & 0.041 & 0.051 & 0.068 & 0.032 \\
\hline G47 & 0.043 & 11 & 0.053 & 7 & 4 & 0.140 & 0.036 & 0.036 & 0.001 \\
\hline $\mathrm{C} 27$ & 0.043 & 12 & 0.044 & 16 & -4 & 0.061 & 0.052 & 0.032 & 0.029 \\
\hline N78 & 0.041 & 13 & 0.049 & 11 & 2 & 0.058 & 0.079 & 0.060 & 0.000 \\
\hline $\mathrm{C} 13$ & 0.041 & 14 & 0.044 & 15 & -1 & 0.036 & 0.097 & 0.040 & 0.003 \\
\hline P85 & 0.040 & 15 & 0.051 & 9 & 6 & 0.144 & 0.027 & 0.033 & 0.000 \\
\hline
\end{tabular}

Source: authors' estimations.

From among 15 divisions, identified as the potentially smart specialisations of the Dolnośląskie voivodeship, the first 4 were indicated irrespective of the SMSS variant and the adopted weights system. The first two divisions - mining of non-ferrous metal ores and production of motor vehicles - received the clearly higher SMSS ratings, which resulted from their relatively high position in the areas essential for smart specialisations, in particular innovation, the scale of the carried out operations and specialisation. The highest rated mining of non-ferrous metal ores division obtained relatively low values in the assessment of the dynamics of changes; however, this did not affect definitely the highest rating.

The high ranking position of PKD divisions characterised either by low or by the absence of innovative activity raises more doubts (44th position of $M R_{4}$ and lower). In general, out of 15 PKD divisions selected in the first step, as many as 4 did not carry out any innovative activities (Table 3), of which two were ranked at high 3rd (detective and security activity) and 4th (creative activity related to culture and entertainment) positions. Such a position resulted from the specialisation significant against the background of other departments and voivodeships and the highest dynamics of changes, indicating an extensive development of these branches. Due to the absence of relevant data, these specialisations were not taken into account in the further 
assessment of RSS. The decision to classify them as smart specialisations should be associated with collecting additional information allowing the verification of their activities in terms of innovative solutions.

The change in the weights system resulted in a relatively large change in the position of one of the divisions selected as the smart specialisation of the Dolnośląskie voivodeship, i.e. C17 division - paper and paper products manufacturing. Taking into account the first 3 components of the aggregate measure illustrating the scale of the phenomenon, specialisation and the dynamics of changes, this division was listed in the middle of the ranking. Its high position is the effects of the scale of the carried out innovation activity, which allowed its advancement to the 7 th position.

Table 4. Smart specialisations of the Dolnośląskie voivodeship in 2017

\begin{tabular}{|c|c|c|c|c|c|c|c|}
\hline \multirow{2}{*}{$\begin{array}{c}\text { Posi- } \\
\text { tion }\end{array}$} & \multirow{2}{*}{\multicolumn{2}{|c|}{ PKD groups }} & \multirow[t]{2}{*}{$S M S S_{W}$} & \multicolumn{4}{|c|}{$\begin{array}{l}\text { Positions of components } \\
\text { by PKD divisions }\end{array}$} \\
\hline & & & & $M R_{1}$ & $M R_{2}$ & $M R_{3}$ & $M R_{4}$ \\
\hline 1 & B07 & mining of non-ferrous metal & 0.267 & 4 & 1 & 69 & 1 \\
\hline 2 & $\mathrm{C} 29$ & $\begin{array}{l}\text { manufacture of motor vehicles, trailers and semi- } \\
\text { trailers, except of motorcycles }\end{array}$ & 0.144 & 1 & 8 & 18 & 2 \\
\hline 5 & $\mathrm{C} 25$ & $\begin{array}{l}\text { manufacture of fabricated metal } \\
\text { products, except machinery and equipment }\end{array}$ & 0.050 & 8 & 32 & 32 & 5 \\
\hline 6 & $\mathrm{C} 28$ & $\begin{array}{l}\text { manufacture of machinery and equipment not elsewhere } \\
\text { classified }\end{array}$ & 0.050 & 12 & 16 & 58 & 4 \\
\hline 7 & $\mathrm{C} 17$ & paper and paper products manufacturing & 0.048 & 33 & 39 & 31 & 3 \\
\hline 8 & G46 & wholesale trade, except of motor vehicles and motorcycles & 0.046 & 5 & 51 & 65 & 12 \\
\hline 9 & $\mathrm{C} 22$ & manufacture of rubber and plastic products & 0.044 & 6 & 22 & 29 & 13 \\
\hline 10 & J62 & information technology and computer service activities & 0.043 & 15 & 21 & 8 & 8 \\
\hline 11 & G47 & retail trade, except of motor vehicles and motorcycles & 0.043 & 3 & 40 & 41 & 32 \\
\hline 12 & $\mathrm{C} 27$ & manufacture of electrical equipment & 0.043 & 10 & 19 & 57 & 9 \\
\hline 14 & $\mathrm{C} 13$ & textile manufacture & 0.041 & 18 & 4 & 28 & 27 \\
\hline
\end{tabular}

Source: authors' compilation.

Summing up the intelligent specializations of the Dolnośląskie voivodeship, identified and based on SMSS, it should be noted that between the first two specializations of B07 mining of non-ferrous metal and C29 manufacture of motor vehicles, trailers and semi-trailers, except of motorcycles and the subsequent RSS proposals there is a very big difference in assessment, which indicates the dominant regional position of these two industry sectors. 


\subsection{Competitiveness of smart specialisations in the Dolnośląskie voivodeship}

Smart specialisations in the Dolnośląskie voivodeship, identified and based on the existing regional resources, should provide the voivodeship with development potential and a competitive advantage. Among 11 PKD sections recognized as RSS, only in the first of them is Dolnośląskie ranked as the national leader (Figure 2 and Table 5), i.e. mining of non-ferrous metal ores. In the case of the second RSS, i.e. manufacture of motor vehicles, Dolnośląskie is ranked as the second after the Silesia voivodeship, which remains a very strong leader in this sector. Dolnośląskie is also ranked in a strong second position regarding the manufacture of machinery and equipment, division (C28), in which the Wielkopolskie voivodeship takes the position of the leader, and also in terms of textile manufacture where it follows the Lodz voivodeship.

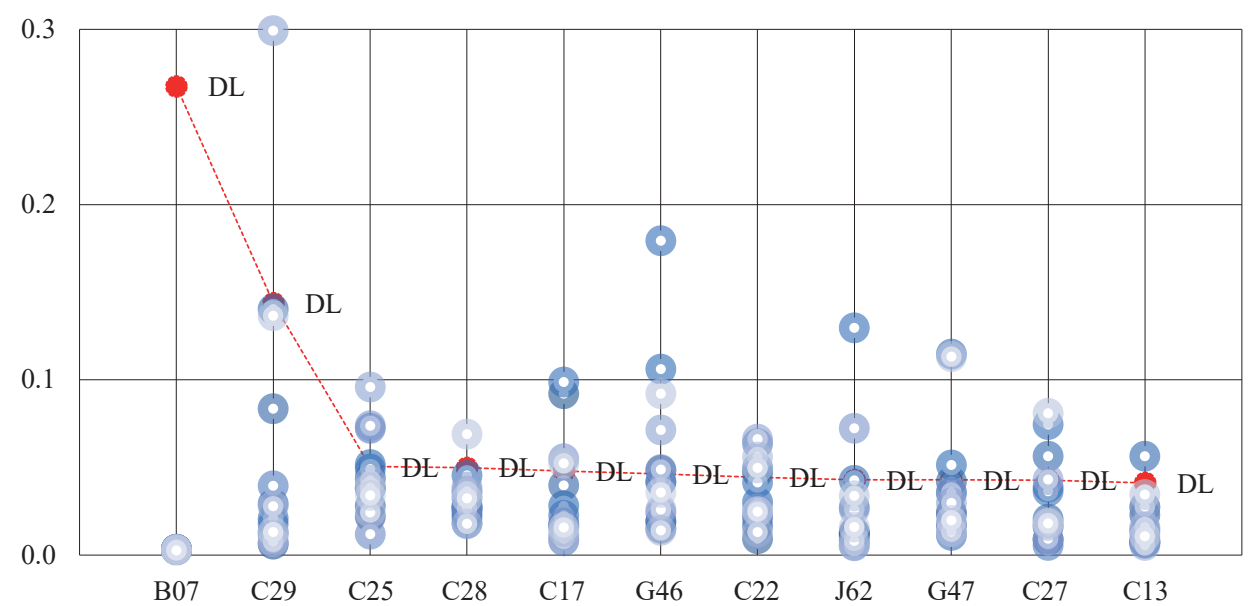

Figure 2. $S M S S_{w}$ values for 11 smart specialisations of Dolnośląskie by voivodeships in 2017 Source: authors' compilation.

A good, third position was also achieved by the Dolnośląskie voivodeship in the area of information technology and computer service activities (Division J62), in which the Mazowieckie voivodeship takes the lead.

Among 11 RSS there are also sections covering retail trade (4th position of the Dolnośląskie voivodeship after Mazowieckie) and wholesale trade (7th position after Mazowieckie). The remaining ranked sectors refer to industrial activity and include the 5th position of Dolnośląskie in the field of: manufacture of metal products (C25) with the Silesia voivodeship as the industry leader, paper and paper products manufacturing $(\mathrm{C} 17)$ where the 
Mazowieckie voivodeship takes the lead, and manufacture of electrical equipment (C27) with the Wielkopolskie voivodeship as the leading one.

Table 5. Smart specialisations of the Dolnośląskie voivodeship in the background of other voivodeships in 2017

\begin{tabular}{|c|c|c|}
\hline PKD groups & $\begin{array}{c}\text { Position of the Dolnośląskie } \\
\text { voivodeship }\end{array}$ & Leader \\
\hline B07 & 1 & Dolnośląskie \\
\hline C29 & 2 & Śląskie \\
\hline C25 & 5 & Śląskie \\
\hline C28 & 2 & Wielkopolskie \\
\hline C17 & 5 & Mazowieckie \\
\hline G46 & 7 & Mazowieckie \\
\hline C22 & 7 & Śląskie \\
\hline J62 & 3 & Mazowieckie \\
\hline G47 & 4 & Mazowieckie \\
\hline C27 & 5 & Wielkopolskie \\
\hline C13 & 2 & Łódzkie \\
\hline
\end{tabular}

Source: authors' compilation.

On the inter-voivodeship arena, Dolnośląskie is characterised by a strong dominance in one PKD industry sector only, i.e. mining of non-ferrous metal. In the other 3 industries it takes a good second position.

\section{Discussion and conclusions for further research}

The collected results allow for several conclusions which may improve the effects of a statistical analysis aimed at identifying the potential smart specialisations using linear ordering methods with a weights system.

It should be noted that when following the discussed approach, the strong position of industries/services results from a high rating in all or only in one area. ${ }^{1}$ For example, when assessing the situation in terms of the scale of operations expressed by the $M R_{1}$ measure presenting employment (P), revenues from total activity (C) and from the sales for export (E), in the case of the first two RSS (B07 and C29) export remains slightly stronger (E) than employment (P),

\footnotetext{
1 More results on the selected indicators for the Dolnośląskie voivodeship see: Bal-Domańska at al. (2018).
} 
whereas the position of division G47 results primarily from the scale of employment (P) and revenues from the performed activity $(\mathrm{C})$ with a minimal role of export (E) (Table 6).

Table 6. $M R_{1}$ values and its components (normalized values) for 11 smart specialisations of the Dolnośląskie voivodeship in 2017

\begin{tabular}{|c|c|c|c|c|c|}
\hline \multicolumn{2}{|c|}{ PKD divisions } & $M R_{1}$ & $P$ & $C$ & $E$ \\
\hline 1 & B07 & 0,139 & 0,098 & 0,074 & 0,244 \\
\hline 2 & C29 & 0,245 & 0,173 & 0,126 & 0,437 \\
\hline 5 & $\mathrm{C} 25$ & 0,081 & 0,130 & 0,032 & 0,083 \\
\hline 6 & $\mathrm{C} 28$ & 0,055 & 0,071 & 0,024 & 0,071 \\
\hline 7 & C17 & 0,016 & 0,022 & 0,017 & 0,010 \\
\hline 8 & G46 & 0,135 & 0,154 & 0,180 & 0,071 \\
\hline 9 & $\mathrm{C} 22$ & 0,090 & 0,104 & 0,045 & 0,120 \\
\hline 10 & $J 62$ & 0,041 & 0,074 & 0,013 & 0,037 \\
\hline 11 & G47 & 0,140 & 0,285 & 0,103 & 0,030 \\
\hline 12 & $\mathrm{C} 27$ & 0,061 & 0,067 & 0,029 & 0,087 \\
\hline 14 & $\mathrm{C} 13$ & 0,036 & 0,043 & 0,013 & 0,052 \\
\hline 15 & P85 & 0,144 & 0,432 & 0,000 & 0,000 \\
\hline
\end{tabular}

Source: authors' calculations in an Excel spread sheet.

In case of MR sub-measures, e.g. $\mathrm{C} 17$ division presenting evidently low values of $P, C$ and $E$ component variables, and thus low values of the $M R_{1}$ measure. Its high ranking position results from high innovation activity (see Tables 3 and 4). However, the relatively low values of the $P, C, E$ component variables and $M R_{1}$ measure were made up for by the relatively strong level of regional specialisation $\left(M R_{2}\right)$ (see Table. 4$)$.

In identifying this type of situation, an in-depth analysis of SMSS components as well as all indicators is necessary. Additionally, to emphasize the role of selected indicators included in the individual $M R_{1}, M R_{2}, M R_{3}$ sub-measures, it is also possible to introduce a weight system at the level of the $P, E$ and $S$ variables.

In the presented approach, RSS identification was based on the full set of objects, even when data availability was limited (no requiredness condition). It means that the failure to include the data on innovation did not eliminate the object (in this case PKD division) from further analysis. As a result, four divisions featuring unknown or zero level of innovation were qualified within the first 15 . These divisions were eliminated at the last stage of the conducted analysis. A positive aspect of the presented approach is the comprehensive assessment and full identification of the regional resources and capital, which may subsequently result in searching for correlations and interdisciplinary cooperation, also between public and private 
sectors. An alternative can take the form of narrowing the analysis down to innovation sections (imposing the requiredness condition), i.e. the ones for which it is possible to quantify innovation activities. In this case, the analysis should be based on the B to N PKD sections.

The requiredness condition may also be imposed on other factors covered by the analysis, in particular the variables. In the case of the sub-measures $M R_{1}-M R_{3}$, which were based on the $P, C$ and $E$ variable values, not all values were always observed, e.g. not every activity is related to export sales. Having assumed the strengthening of competitiveness on the international market, it is possible to tighten this criterion by imposing a weights system or by eliminating the "non-export" sections. It should, however, be remembered that the analysis was carried out for the total of 16 voivodeships and the presence of "export" position in possible only in the selected voivodeships. Therefore, the application of a weights system is suggested as a more favourable solution.

\section{Conclusions}

Answering the questions formulated at the beginning, it should be stated that RSS identification using aggregate measures results in positive effects allowing for the identification of strongly developed, innovative or dynamically entering the market sectors of industry and services. The synthetic variable is not directly observable (so-called hidden variable), while its values are based on the obtained directly measurable diagnostic variables. The strength of statistical methods is not only the recognition of the endogenous potentials ingrained in the region, but also the ability to assess the region's competitive advantages against other regions. The introduced system of weights should be assessed positively. Although it has been defined in an arbitrary way, it seems to reflect the intentions well enough and improves the ranking of these industry sectors which meet the imposed criteria and are characterized by high innovation and specialization.

The identified industry sectors should not be approached as ultimate smart specializations, but rather as the industries which may constitute an important component in the construction of the more broadly defined regional specializations based, e.g., on value chains.

In the Dolnośląskie voivodeship, the still valid strategic document defining the region's challenges in terms of building a knowledge-based economy and increasing innovation is the "Regional Innovation Strategy for the Dolnośląskie Voivodeship 2011-2020”, supplemented by an attachment entitled "Strategic Framework for Smart Specializations of Dolnośląskie" (UMWD, 2015), containing the areas of smart specialization of Dolnośląskie proposed as 
a result of a SWOT analysis. At that time, these key areas with the largest development potential at present were:

1. Chemical and pharmaceutical industry.

2. Spatial mobility.

3. High quality food.

4. Natural resources and recyclable materials.

5. Machines and equipment manufacturing, materials processing technology.

6. Information and communication technologies (ICTs).

The intelligent specializations of the Dolnośląskie voivodeship identified in this article, ensuring its development potential and competitive advantage - high values of SMSS measure (in particular PKD divisions: B07, C29, C28 and J62) can be assigned to the areas listed in the Annex to RSI for the Dolnośląskie voivodeship 2011-2020: 4. Natural resources and recyclable materials, 2. Spatial mobility and 6. Information and communication technologies (ICTs). However, 3 PKD divisions (G46; G47 and C13) were not determined as a result of a SWOT analysis.

\section{References}

Bal-Domańska, B., Cybulski, L., Kamiński, S., Ładysz, I., Stańczyk, E. (2018). Monitoring of Intelligent Context Specialization in Dolnośląskie voivodship. Urząd Statystyczny we Wrocławiu. Retrieved from: https://wroclaw.stat.gov.pl/wspolpraca-w-regionie/projektyanalityczno-badawcze.

Bąk, A. (1999). Modelowanie symulacyjne wybranych algorytmów wielowymiarowej analizy porównawczej w języku C++ [Simulation modelling of selected algorithms in multivariate comparative analysis in $\mathrm{C}++$ ]. Wrocław: Wrocław University of Economics Press.

Borys, T. (1984). Kategoria jakości w statystycznej analizie porównawczej [Quality category in statistical comparative analysis]. Prace Naukowe Uniwersytetu Ekonomicznego we Wrocławiu, 284. Monografie i Opracowania, 23.

Capello, R. (2014). Smart specialisation strategy and the new EU cohesion policy reform: Introductory remarks. Scienze Regionali, 13 (1), 5-15.

European Commission (2012). Guide on Research and Innovation Strategies for Smart Specialisation (RIS 3). Luxemburg: Publication Office of the European Union. 
European Commission (2010). Europe 2020: A European strategy for smart, sustainable and inclusive growth. Brussels: Publication Office of the European Union.

European Commission (2012). Guide to Research and Innovation Strategies for Smart Specialisation (RIS 3).

Foray, D. (2015). Smart Specialisation - Opportunities and challenges for Regional Innovation Policy. London: Routledge.

Foray, D., David, P.A., Hall, B.H. (2011). Smart specialisation from academic idea to political instrument, the surprising career of a concept and the difficulties involved in its implementation. METI Working Paper, pp. 2011-001.

Geodecki, T., Gorzelak, G., Górniak, J., Hausner, J., Mazur, S., Szlachta, J., Zaleski, J. (2013). Kurs na innowacje. Jak wyprowadzić Polskę z rozwojowego dryfu? (Course for innovation. How to get Poland out of its developmental drift?). Kraków: Fundacja Rozwoju i Administracji Publicznej [Public Development and Administration Foundation].

Grabiński, T. (1984). Wielowymiarowa analiza porównawcza w badaniach dynamiki zjawisk ekonomicznych [Multivariate comparative analysis in the studies of the dynamics of economic phenomena]. Zeszyty Naukowe Uniwersytetu Ekonomicznego w Krakowie. Monografie, 61.

IRE (2016). Innovative Regions in Europe Network. RIS Methodological Guide, Stage 1, IRE Secretariat.

Landabaso, M., Foray, D. (2014). From smart specialisation to smart specialisation policy. European Journal of Innovation Management, 17 (4), 492-507.

Landabaso, M., McCann, P., Ortega-Argilés, R. (2014). Smart specialisation in European regions: Issues of strategy, institutions and implementation. European Journal of Innovation Management, 17 (4), 409-427.

Lopes, J., Ferreira, J.J., Farinha, L. (2019). Innovation strategies for smart specialisation (RIS3): Past, present and future research. Growth and Change, 50, 38-68.

Peszat, K., Szlachta, J. (2017). Changing the development path of a region - a case study of the Lower Silesian Voivodship. Miscellanea Geographica - Region al Studies on Development, 21 (2), 84-88. DOI: 10.1515/mgrsd-2017-0026.

UMWD/ The Marshall's Office of Dolnośląskie Voivodeship (2015). Ramy strategiczne na rzecz inteligentnych specjalizacji Dolnego Śląska [Strategic frameworks for Smart Specialisations of Dolnośląskie Voivodeship]. Attachment to RSI for Dolnośląskie Voivodeship 2011-2020. Wrocław: UMWD.

UMWP/Marshal Office of the West Pomerania Voivodeship (2014). Assumptions for the process of smart specialisations identification of the West Pomerania Voivodeship. Department of Strategic Management, Marshal Office of the West Pomeranian Voivodeship, Szczecin. 
UMWS/Marshal Office of the Silesia Voivodeship (2018). The list of smart specialisations of the Silesia Voivodeship. Update, Katowice.

Walesiak, M. (2011). Uogólniona miara odległości GDMw statystycznej analizie wielowymiarowej [Generalized distance measure GDM in multivariate statistical analysis]. Wrocław: Wrocław University of Economics Press. 